\title{
Protein SSX4
}

National Cancer Institute

\section{Source}

National Cancer Institute. Protein SSX4. NCI Thesaurus. Code C97818.

Protein SSX4 (188 aa, $\sim 22 \mathrm{kDa}$ ) is encoded by the human SSX4 and SSX4B genes. This protein may be involved in the regulation of transcription. 